Administrative Issues Journal: Connecting Education, Practice, and Research, Winter 2017, Vol. 7, No. 2: 70-80. DOI: 10.5929/2017.7.2.1

\title{
How managers use the Stockdale Paradox to balance "the now and the next"
}

\author{
C. W. Von Bergen, Ph.D. \\ Martin S. Bressler, Ed. D. \\ Southeastern Oklahoma State University
}

\begin{abstract}
Recent discussions of leadership paradoxes have suggested that managers who can hold seemingly opposed, yet interrelated perspectives, are more adaptive and effective. One such paradox that has received relatively little attention is the "Stockdale Paradox," named after Admiral James Stockdale, an American naval officer who was held captive for seven and one-half years during the Vietnam War and survived imprisonment in large part because he held beliefs of optimism about the future, while simultaneously acknowledging the current reality of the desperate situation in which he found himself. This contradictory tension enabled him and his followers to emerge from their situation not just unbroken, but stronger. Such paradoxical thinking has been empirically supported by mental contrasting research demonstrating the effectiveness of visualizing a positive future yet recognizing the reality of the current situation. This apparent dichotomy provides an important lesson for leaders who must remain optimistic, yet face the reality of their present condition, and is symbolic of an overarching, general tension leaders face in addressing "the now and the next."
\end{abstract}

Keywords: leadership, Stockdale Paradox, positivity, mental contrasting

"You must maintain unwavering faith that you can and will prevail in the end, regardless of the difficulties - and at the same time, have the discipline to confront the most brutal facts of your current reality, whatever they may be." - Admiral James Stockdale

\footnotetext{
The business environment has increased in turbulence, change, and complexity, which has heightened the awareness of competing tensions, such as those that characterize paradoxes (Clegg, Cuhna, \& Cuhna, 2002). Paradox was introduced as a framework to deal with the inherent complexity of organizational life by Cameron and Quinn (1988). In the Greek etymological sense of the word, "para" meaning "contrary" and "doxa" meaning "accepted opinion," paradoxes involve the juxtaposition of two incompatible and conflicting theses (Putnam, 1986; Statler, Heracleous, \& Jacobs, 2011; Stohl \& Cheney, 2001). As an example, Plato demonstrated a paradox when he said: "I am the wisest
}

VON BERGEN, MASSEY, \& BRESSLER / DOI: 10.5929/2017.7.2.1 
man alive, for I know one thing, and that is that I know nothing." The notion of paradox has been defined as "contradictory yet interrelated elements-elements that seem logical in isolation but absurd and irrational when appearing simultaneously" (Lewis, 2000, p. 760).

Leaders comfortable with paradox are said to exhibit cognitive complexity in the sense that "the test of a first-rate leader may be the ability to exhibit contrary or opposing behaviors as appropriate or necessary while still retaining some measure of integrity, credibility, and direction" (Denison, Hooijberg, \& Quinn, 1995, p. 526). Ellis (2014) noted that leaders need to be humble and strong, decisive, and willing to listen to the ideas of others, confident and vulnerable, tough and compassionate, and detached and sensitive. Zhang, Waldman, Han, and Li (2015) empirically derived five dimensions of paradoxical leader behavior at supervisory levels: (1) combining self-centeredness with other-centeredness; (2) maintaining both distance and closeness; (3) treating subordinates uniformly while allowing individualization; (4) maintaining decision control while allowing autonomy; and (5) enforcing work requirements while allowing flexibility. Leadership behavior is necessary to bring together or integrate these complex/diverse elements (Waldman \& Bowen, 2016).

One overarching paradox that leaders must address is what Waldman and Bowen (2016) refer to as "the now and the next" (p. 319), a term coined by Dr. Caren Siehl at Arizona State University in her description of how a firm's current demands often complicate the change efforts of leaders. The dynamic nature of organizational environments demands that leaders deal with change, with an eye on both the present and the future. In other words, organizations need to be reactive to demands in the present while simultaneously being proactive about the need for broader sweeping change in the future. Thus, effective leaders deal with the tensions of simultaneously enacting both continuity and change, they address both short-term pressures and long-term demands-they deal successfully with the now/next paradox. A paradox-savvy leader can simultaneously deal with the "now" context while also addressing the "future." One excellent example of an effective leader focusing on the overarching tension involving both the present and the future was Admiral James Stockdale.

\section{James Stockdale}

James Stockdale was a U.S. naval aviator who was shot down in a combat mission over North Vietnam on September 9, 1965, and was the senior naval officer held captive as an American prisoner of war for over seven and one-half years. He was tortured over 20 times and denied medical attention for a severely injured leg he endured during capture. Stockdale led a prison resistance movement, and created and enforced a code of conduct for all U.S. prisoners that governed torture, secret communications, and behavior. After his release, he was promoted to Vice Admiral, and on March 4, 1976, he was awarded the Congressional Medal of Honor, the nation's highest military accolade.

\section{The Stockdale Paradox}

In his book, Good to Great (2001), Collins and his team studied firms that made the transition from mediocre to outstanding performance and found that great organizations embraced the "Stockdale Paradox" (p. 85), named after Admiral Stockdale, which involved the right mix of optimism and a willingness to confront the cruel facts of reality. According to Stockdale, individuals must never confuse

VON BERGEN, MASSEY, \& BRESSLER / DOI: 10.5929/2017.7.2.1 
faith that in the future they will prevail, regardless of the difficulties, with the discipline to confront the harsh facts of their current reality. Stockdale indicated that those persons who did not survive the barbarity of being prisoners of war were the optimists:

They were the ones who said, "We're going to be out by Christmas." And Christmas would come, and Christmas would go. Then they'd say, "We're going to be out by Easter." And Easter would come, and Easter would go. And then Thanksgiving, and then it would be Christmas again. And they died of a broken heart. (Collins, 2001, p. 84)

Stockdale further noted, "You must never confuse faith that you will prevail in the end-which you can never afford to lose-with the discipline to confront the most brutal facts of your current reality, whatever they might be" (Collins, 2001, p. 83). "I never lost faith in the end of the story," Stockdale said; "I never doubted not only that I would get out, but also that I would prevail in the end and turn the experience into the defining event of my life, which, in retrospect, I would not trade" (Collins, 2001, p. 83).

On an organizational level, such a duality guards against the endless disappointment that optimism often creates. Confronting the adversity of the current state enables organizations to make realistic assessments of their current situation to allocate energies and reserves to better face each challenge as it comes, thus positioning the enterprise with a stronger chance to prevail. The Stockdale Paradox, then, seems to involve both being positive (retain faith that you will prevail in the end regardless of the difficulties) and at the same time, being realistic, what some would call, negative (confront the most brutal facts of your current reality, whatever they might be), and a balance in both seems to be important to survival. Thus, the unwavering faith in the endgame in combination with a stoic acceptance of the horridness of the current reality can serve to clarify the dangers of excessive optimism for both individuals and organizations. What the optimists and positive thinkers among the prisoners of war failed to do was confront the reality of their situation. That self-delusion might have made it easier on them in the shortterm, but when they were eventually forced to face reality, it had become too much, and they could not handle it.

Interestingly, the Stockdale Paradox is like famous psychotherapist and holocaust survivor Viktor Frankl's (1959) experience in several German concentration camps in World War II. Frankl observed that the death rate in the German concentration camps increased close to Christmas because many people who believed they would be spending it with their family died of disappointment. He developed the concept of "tragic optimism, that is, an optimism in the face of tragedy" (Frankl, 1959, p. 139). It refers to the capacity to hope despite, and because of, tragic experiences. Tragic optimism is predicated on the defiant human spirit, the Nietzschean view that what cannot destroy a person makes them stronger. It has no use for wishful thinking or positive illusions, and is based, in part, on acceptance that enables one to confront the reality of what cannot be changed. Tragic optimism is similar to the Stockdale Paradox in that both expressed a duality involving the acknowledgement of the difficulties of the current situation and the positive belief that in the end, they would triumph.

VON BERGEN, MASSEY, \& BRESSLER / DOI: 10.5929/2017.7.2.1 


\section{Implications of the Stockdale Paradox}

A key learning point of the Stockdale Paradox is that the overemphasis on being positive, cheerful, upbeat, and optimistic seen in today's American culture may be misguided. There is perhaps no virtue more desirable in Western civilization than being positive (Judge \& Ilies, 2004) and this belief continues today as philosophers, theologians, counseling and sports psychologists, and authors of self-help books have placed heavy emphasis on looking on the bright side as a means of achieving personal growth and effectiveness, satisfaction, productivity, good health, prosperity, and success (Ehrenreich, 2009; Fineman, 2006; Judge, Erez, \& Bono, 1998; Neck \& Manz, 2007). American pop psychology has always been explicitly positive, with the Dale Carnegies, Napoleon Hills, Werner Erhards, Zig Ziglars, and Tony Robbins's of the world holding high honor. Indeed, we are told that "if your life does not get better, it is your fault-your thoughts were not positive enough" (Shermer, 2006).

Being positive has also taken firm root within the corporate world. Cultural norms about good business practice stress looking at the sunny side and deemphasizing the problematic. Sales meetings now resemble political rallies or revivals. Seligman (1991) reported that optimistic salespersons had higher performance and lower attrition than their lesser optimistic cohorts at a life insurance company. Likewise, Luthans and his collaborators (Luthans, Avolio, Avey, \& Norman, 2007; Luthans \& Youssef, 2007) found that their concept of psychological capital, key components of which include confidence and optimism, was positively related to performance outcomes in the workplace, such as lower employee absenteeism, less employee cynicism and intentions to quit, and higher job satisfaction, commitment, and organizational citizenship behaviors. CEOs are coming to think of themselves as motivators geared toward persuading employees to work harder for less pay and no job security.

Historically, the science of management was that of a rational enterprise, where spreadsheets were developed, logic trees were created, and decisions were made based on careful analysis. All that was swept aside for a new notion of what management is about. The word now used is leadershipparticularly the charismatic and transformational leadership models (Yukl, 2002)-where senior executives are primarily charged with inspiring the workforce.

The point Stockdale (and Frankl) make, however, is that it is maladaptive to only have optimism and positivity. This is consistent with Daniels' (2001) counsel that "always be positive is the worst advice you could give or receive" (p. 44). Sometimes, Daniels suggests, a (metaphorically speaking) swift kick in the behind is what is called for. Blind optimists who think that everything will be fine if they just sit back and have positive thoughts and wait will be bitterly disappointed. At the same time, leaders should never lose hope that they will overcome adversity in the end, no matter what fate has presented. Stockdale stressed the capacity to constructively face tensions and, rather than choosing one perspective at the expense of the other, to incorporate both views simultaneously. Thus, being realistic and, at times, accepting the negatives associated with "the now" coupled with an optimistic view of "the next" was a characteristic of Admiral Stockdale and great companies identified by Collins (2001).

The Stockdale Paradox and its emphasis on the "now and the next" has received substantial empirical support. Oettingen and her colleagues (e.g. Gollwitzer, Oettingen, Kirby, Duckworth, \& Mayer, 2011; Kappes \& Oettingen, 2011; Kappes, Singmann, \& Oettingen, 2012; Oettingen, 2014; Oettingen \& Wadden,

VON BERGEN, MASSEY, \& BRESSLER / DOI: 10.5929/2017.7.2.1 
1991) have employed a protocol called "mental contrasting" that requires individuals to consider both positive and negative features of goal achievement. In mental contrasting, individuals imagine achieving a desired future/goal (e.g. becoming a physician, writing an article) and then think about obstacles that may currently stand in their way (e.g. education costs, excessive partying). When study participants have performed mental contrasting, they have come away more energized and achieved better results compared with participants who either only positively fantasized about their goal or only focused on impediments.

In one study by Gollwitzer et al. (2011) a group of third graders were told to imagine a candy prize they would receive if they finished a language assignment and then to imagine several of their own behaviors that could prevent them from winning the award. A second group of students was instructed only to fantasize about winning the prize. The students who did the mental contrasting outperformed those who just fantasized about it. In another study, Oettingen and Walden (1991) performed a weight loss investigation. One group of women were told to vividly imagine that they had succeeded and lost weight, and another group of women were asked to visualize themselves achieving the weight loss goal, but also to imagine situations in which they cheated on their diets-a reality for most individuals. A year later, the women who only pictured their successful weight reduction lost less weight than the ones who pictured their attained weight loss goal and possible stumbling blocks.

These studies and others suggest that when people focus on only positive thoughts about the future, they literally trick their minds into thinking they have already succeeded and, so, do not need actual efforts to attain something perceived as already acquired. However, completely disregarding positive thinking is also not effective. With purely negative thoughts, people convince themselves that they have already lost the goal, so, again, there is no need to make the efforts necessary to achieve it. What is needed is both a positive focus on the future and a recognition of problems and difficulties that are likely to hinder their success. Interestingly, Kappes et al. (2012) found that sequencing was important in mental contrasting. Such a practice was effective only when the positive goal was considered first followed by a reflection on potential obstacles.

\section{Summary and Conclusion}

Positive thinking, or positivity, has become more commonplace since the Reverend Dr. Norman Vincent Peale published his classic book The Power of Positive Thinking in 1952. Today, with more than five million copies in print, leaders in almost every field of endeavor espouse the power of thinking positively. Keith (2017), for example, points to newly elected President Donald Trump, who on several occasions referred to Peale and his book. President Trump, in fact, knew the Reverend Dr. Peale for many years and referred to him as "my pastor" (Keith, 2017). This emphasis on the positive and being positive continues today, and academia has made room for the new disciplines of "positive psychology" (Seligman \& Pawelski, 2003), "positive organizational behavior" (Luthans \& Youssef, 2007), and "appreciative inquiry" (Cooperrider \& Sekerka, 2003).

Some researchers, however, have found that too much positive thinking can be detrimental. For instance, Von Bergen and Bressler (2011) found with entrepreneurs that too much positive thinking hinders success. Rather, entrepreneurs need to temper their optimism with reality. In business, viewing the world with

VON BERGEN, MASSEY, \& BRESSLER / DOI: 10.5929/2017.7.2.1 
"rose colored glasses" can lead to business failure and financial ruin. Similarly, Finkelstein (2003) conducted a six-year examination of 51 companies and found that executives of failed companies clung to an inaccurate view of reality that consistently underestimated obstacles. Finkelstein (2003) noted that "blind adherence to 'positive thinking' became a dominant corporate value that was often at the foundation of organizational failure" (pp. 2-3). The executives' view of the future undermined the realities of the present. When reality surfaced, it was often whitewashed for reasons of face-saving and hubris. The downside of positive thinking has also been documented by Ehrenreich (2009) in many areas (e.g., financial, medical, political, religious, and the military). What is needed is a more nuanced view of positive thinking that involves both positive thinking about the future and concurrent consideration of the realities of the present, and that is where the Stockdale Paradox comes in.

\section{Implications of the Stockdale Paradox}

Managers are in a constant struggle, balancing optimism and reality. Honan (2016) used the Stockdale Paradox to describe how optimism creates resilience. Honan pointed to the research of Dr. Dennis Charney, a psychiatrist researching new treatments for anxiety disorders. According to Honan (2016), Stockdale's optimism came from social support. Despite being held in solitary confinement while in prison in North Vietnam, he and his followers developed a code to communicate to the other prisoners. That code was the basis for their communication and social support, which in some cases developed into lifelong friendships.

This suggests both managers and organizations need to understand the importance of social support and develop communications and other support mechanisms to attain that end. This could be especially important when organizations are struggling through difficult financial times or facing other challenges. Managers must be able to take on the role of coach and cheerleader, while at the same time overcoming adverse business conditions; that is, leaders must accept and balance paradoxes at the same time (Smith \& Lewis, 2011).

The importance of practicing such paradoxical leadership was noted several decades ago by well-known essayist, F. Scott Fitzgerald (1936), who observed that "the test of a first-rate intelligence is the ability to hold two opposed ideas in the mind at the same time and still retain the ability to function." Such paradoxsavvy leaders (Waldman \& Bowen, 2016) often engage in holistic, integrative thinking and view elements in the universe as continuous, interconnected, and interpenetrated (Koo \& Choi, 2005; Masuda \& Nisbett, 2001). Martin (2009) found that the ability to leverage tensions was the most striking and consistent feature that enabled outstanding leaders to be agile and flexible and to achieve long-term success-which Stockdale did as one of the nation's longest surviving prisoners of war. One principal paradox due to the dynamic nature of organizational environments demands that leaders address current matters and future considerations, and effective leaders must keep an eye on both.

The Stockdale Paradox discussed here requires individuals to focus on both the present and the future. Such a duality was utilized by Admiral Stockdale in balancing a hopeful future with the undesirable now, which enabled him and his followers to survive the hardships of being prisoners of war. This tension has sometimes been referred to as organizational ambidexterity (Duncan, 1976) defined as the ability to pursue two disparate things at the same time. The idea of ambidexterity, say O'Reilly and Tushman (2016),

VON BERGEN, MASSEY, \& BRESSLER / DOI: 10.5929/2017.7.2.1 
is that firms must remain competitive in their present core markets by exploitation, which seeks incremental innovation to deepen current knowledge and capabilities that nurture greater efficiency and continuous improvements, and exploration, which fuels radical innovation through experimentation and research and development that seeks new knowledge, technologies, and markets to achieve long-term sustainability.

In March's (1991) view, "The basic problem confronting an organization is to engage in sufficient exploitation to ensure its current viability and, at the same time, devote enough energy to exploration to ensure its future viability" (p. 105). Ambidexterity studies show that organizations that achieve a balance between these inherently conflicting efforts and then cope with tensions that arise from the conflict between them without losing that balance will be more successful than others and is positively correlated with increased innovation, better financial performance (e.g., sales growth), and higher survival rates (He \& Wong, 2004; Lubatkin, Simsek, Yan, \& Veiga, 2006; O’Reilly \& Tushman, 2016).

Just as O'Reilly and Tushman (2016) say that all ambidextrous leaders ask, "How can we both exploit existing assets and capabilities by getting more efficient and provide for sufficient exploration so that we are not rendered irrelevant by changes in markets and technologies?" (p. 12), so too should all leaders question like Stockdale, "How can we maintain a realistic view of our current situation and yet preserve the belief that in the end we will prevail?" How can leaders keep an eye on both the present ("the now") and the future ("the next")?

\section{References}

Andriopoulos, C., \& Lewis, M. W. (2009). Exploitation-exploration tensions and organizational ambidexterity: Managing paradoxes of innovation. Organization Science, 20(4), 696-717.

Cameron, K. S., \& Quinn, R. E. (1988). Organizational paradox and transformation. In R. E. Quinn \& K. S. Cameron (Eds.), Paradox and transformation: Toward a theory of change in organization and management (pp. 1-18). Cambridge, MA: Ballinger.

Clegg, S. R., Cuhna, J. V., \& Cuhna, M. P. (2002). Management paradoxes: A relational view. Human Relations, 55(5), 483-505.

Collins, J. C. (2001). Good to great: Why some companies make the leap ... and others don't. New York: Harper Business.

Cooperrider, D. L., \& Sekerka, L. E. (2003). Toward a theory of positive organizational change. In K. S. Cameron, J. E. Dutton, \& R. E. Quinn (Eds.), Positive organizational scholarship: Foundations of a new discipline (pp. 225-240). San Francisco: Berrett-Koehler.

Daniels, A. C. (2001). Other people's habits: How to use positive reinforcement to bring out the best in people around you. New York: McGraw-Hill.

Denison, D. R., Hooijberg, R., \& Quinn, R. (1995). Paradox and performance: Toward a theory of behavioral complexity in managerial leadership. Organization Science, 6(5), 524-540.

VON BERGEN, MASSEY, \& BRESSLER / DOI: 10.5929/2017.7.2.1 
Duncan, R. (1976). The ambidextrous organization: Designing dual structures for innovation. In R. J. Killman, L. R. Pondy, \& D. Sleven (Eds.), The management of organization (pp. 167-188). New York: North Holland.

Ehrenreich, B. (2009). Bright-sided: How the relentless promotion of positive thinking has undermined America. New York: Metropolitan Books.

Ellis, L (2014). The Paradox of Faith vs. Reality. Retrieved from http://www.sbnonline.com/article/leeellis-what-s-your-leadership-vision-for-the-new-year-2/

Evans, P. (1999). HRM on the edge: A duality perspective. Organization, 6(2), 325-338.

Fineman, S. (2006). On being positive: Concerns and counterpoints. Academy of Management Review, 31(2), 270-291.

Finkelstein, S. (2003). Why smart executives fail, and what you can learn from their mistakes. New York: Penguin Group.

Fiol, C. M. (2002). Capitalizing on paradox: The role of language in transforming organizational identities. Organization Science, 13(6), 653-666.

Fitzgerald, F. S. (1936). The crack-up. Retrieved from Esquire, The Crack-Up, from http://www.esquire .com/features/thecrackup

Frankl, V. E. (1959). Man's search for meaning. Boston: Beacon Press.

Gollwitzer, A., Oettingen, G., Kirby, T., Duckworth, A., \& Mayer, D. (2011). Mental contrasting facilitates academic performance in school children. Motivation and Emotion, 35, 403-412.

He, Z., \& Wong, P. (2004). Exploration vs. exploitation: An empirical test of the ambidexterity hypothesis. Organization Science, 15(4), 481-494.

Honan, D. (2016). The Stockdale Paradox: How Optimism Creates Resilience. Retrieved 04/20/2017 from http://bigthink.com/think-tank/the-stockdale-paradox-how-optimism-creates-resilience

Huy, Q. N. (2002). Emotional balancing of organizational continuity and radical change: The contribution of middle managers. Administrative Science Quarterly, 47(1), 31-69.

Jarzabkowski, P., Lê, J., \& Van De Ven, A. (2013). Responding to competing strategic demands: How organizing, belonging, and performing paradoxes coevolve. Strategic Organization, 11(3), 245280.

Jarzabkowski, P., \& Sillince, J. (2007). A rhetoric-in-context approach to building commitment to multiple strategic goals. Organization Studies, 28(11), 1639-1665.

Judge, T. A., Erez, A., \& Bono, J. E. (1998). The power of being positive: The relation between positive selfconcept and job performance. Human Performance, 11(2/3), 167-187.

Judge, T. A., \& Ilies, R. (2004). Is positiveness in organizations always desirable? Academy of Management Executive, 18(4), 151-155.

VON BERGEN, MASSEY, \& BRESSLER / DOI: 10.5929/2017.7.2.1 
Kappes, H. B., \& Oettingen, G. (2011). Positive fantasies about idealized futures sap energy. Journal of Experimental Social Psychology, 47(4), 719-729.

Kappes, A., Singmann, H., \& Oettingen, G. (2012). Mental contrasting instigates goal pursuit by linking obstacles of reality with instrumental behavior. Journal of Experimental Social Psychology, 48(4), 811-818.

Keith, T. (2017, January 22). Trump Crowd Size Estimate May Involve 'The Power of Positive Thinking'. National Public Radio. Retrieved 04/28/2017 from http://www.npr.org/2017/01/22/510655254 trump-crowd-size-estimate-may-involve-the-power-of-positive-thinking

Koo, M., \& Choi, I. (2005). Becoming a holistic thinker: Training effect of oriental medicine on reasoning. Personality and Social Psychology Bulletin, 31(9), 1264-1272.

Lewis, M. W. (2000). Exploring paradox: Toward a more comprehensive guide. Academy of Management Review, 25(4), 760-776.

Lewis, M. W., \& Smith, W. K. (2014). Paradox as a metatheoretical perspective: Sharpening the focus and widening the scope. Journal of Applied Behavioral Science, 50(2), 127-149.

Lubatkin, M., Simsek, Z., Yan, L., \& Veiga, J. (2006). Ambidexterity and performance in small- to mediumsized firms: The pivotal role of top management team behavioral integration. Journal of Management, 32(5), 646-672.

Lüscher, L. S., \& Lewis, M. W. (2008). Organizational change and managerial sensemaking: Working through paradox. Academy of Management Journal, 51(2), 221-240.

Luthans, F., Avolio, B. J., Avey, J. B., \& Norman, S. M. (2007). Positive psychological capital: Measurement and relationship with performance and satisfaction. Personnel Psychology, 60(2007), 541-572. Luthans, F., \& Youssef, C. M. (2007). Emerging positive organizational behavior. Journal ofManagement, 33(3), 321-349.

March, J. (1991). Exploration and exploitation in organizational learning. Organization Science, 2(1), 7187.

Martin, R. (2009). The opposable mind: Winning through integrative thinking. Boston, MA: Harvard Business School Publishing.

Masuda, T., \& Nisbett, R. E. (2001). Attending holistically versus analytically: Comparing the context sensitivity of Japanese and Americans. Journal of Personality and Social Psychology, 81(5), 922934.

Oettingen, G. (2014). Rethinking positive thinking: Inside the new science of motivation. New York: Penguin.

Oettingen, G., \& Wadden, T. A. (1991). Expectation, fantasy, and weight loss: Is the impact of positive thinking always positive? Cognitive Therapy and Research, 15(2), 167-175.

VON BERGEN, MASSEY, \& BRESSLER / DOI: 10.5929/2017.7.2.1 
O’Reilly, C. A., \& Tushman, M. L. (2016). Lead and disrupt: How to solve the innovator's dilemma. Stanford, CA: Stanford University Press.

Neck, C., \& Manz, C. (2007). Mastering self-leadership: Empowering yourself for personal excellence (4 ${ }^{\text {th }}$ ed.). Upper Saddle River, NJ: Prentice Hall.

Peale, N. V. (1952). The power of positive thinking. New York: Prentice Hall.

Putnam, L. (1986). Contradictions and paradoxes in organizations. In L. Thayer (Ed.), Organization communications: Emerging perspectives (pp. 151-167). Norwood, NJ: Ablex.

Seligman, M. E. P. (1991). Learned optimism. New York: Knopf.

Seligman, M. E. P., \& Pawelski, J. O. (2003). Positive psychology: FAQs. Psychological Inquiry, 14(2), 159169.

Shermer, M. (2006). Sham Scam. The Self-Help and Actualization Movement Has Become an \$8.5-billiona-year Business. Does It Work? Retrieved from http://www.scientificamerican.com/article/shamscam/

Smith, W. K., \& Lewis, M. W. (2011). Toward a theory of paradox: A dynamic equilibrium model of organizing. Academy of Management Review, 36(2), 381-403.

Smith, W. K., Lewis, M. W., \& Tushman, M. L. (2016, May). Both/and leadership. Harvard Business Review, 62-70.

Smith, W. K., \& Tushman, M. L. (2005). Managing strategic contradictions: A top management model for managing innovation streams. Organization Science, 16(5), 522-536.

Statler, M., Heracleous, L., \& Jacobs, C. D. (2011). Serious play as a practice of paradox. Journal of Applied Behavioral Science, 47(2), 236-256.

Stohl, C., \& Cheney, G. (2001). Participatory processes/paradoxical practices. Management Communication Quarterly, 14(3), 349-407.

Sundaramurthy, C., \& Lewis, M. (2003). Control and collaboration: Paradoxes of governance.Academy of Management Review, 28(3), 397-415.

Von Bergen, C. W., \& Bressler, M. S. (2011). Too much positive thinking hinders entrepreneur success. Journal of Business and Entrepreneurship, 23(1), 30-52.

Waldman, D. A., \& Bowen, D. E. (2016). Learning to be a paradox-savvy leader. Academy of Management Perspectives, 30(3), 316-327.

Yukl, G. (2002). Leadership in organizations ( $5^{\text {th }}$ ed.). Upper Saddle River, NJ: Prentice Hall.

Zhang, Y., Waldman, D. A., Han, Y. L., \& Li, X. B (2015). Paradoxical leader behaviors in people management: Antecedents and consequences. Academy of Management Journal, 58(2), 538-566.

VON BERGEN, MASSEY, \& BRESSLER / DOI: 10.5929/2017.7.2.1 


\section{About the Authors}

C. W. Von Bergen, Ph.D. (cvonbergen@se.edu) is Professor of Management and the John Massey Chair in Management at Southeastern Oklahoma State University. Dr. Von Bergen has authored more than 100 journal articles in a wide range of publications including Employee Relations Law Journal, Labor Law Journal, and the Journal of Behavioral Studies in Business.

Martin S. Bressler, Ed.D. (mbressler@se.edu) is Professor of Marketing and Management and the John Massey Endowed Chair in Entrepreneurship at Southeastern Oklahoma State University. Dr. Bressler is a Fulbright Scholar and has authored more than 50 academic journal articles on a wide range of topics, in addition to articles in industry publications including Marketing News. 